Organizational Science, pp. 1-20

\title{
A Recursive Perspective on Discursive Legitimation and Organizational Action in Mergers and Acquisitions
}

\author{
Eero Vaara \\ Hanken School of Economics, 00101 Helsinki, Finland, and École de Management de \\ Lyon, 69132 Lyon Ecully Cedex, France, \\ eero.vaara@hanken.fi
}

Philippe Monin

EMLYON Business School, 
This paper challenges the predominant view that legitimation is merely a specific phase in merger or acquisition processes. We argue that a better understanding of postmerger organizational dynamics calls for conceptualization of discursive legitimation as an inherent part of unfolding merger processes. In particular, we focus on the recursive relationship between legitimation and organizational action. We have two objectives: to outline a theoretical model that helps one to understand the dynamics of discursive legitimation and organizational action in postmerger organizations, and to examine a revealing case to distinguish the inherent risks and problems in discursive legitimation. Our case analysis focuses on the merger between the French pharmaceutical companies BioMérieux and Pierre Fabre. We adopt a critical multimethod approach and distinguish specific discursive dynamics and pathological tendencies in this case. The analysis highlights the unintended consequences of discursive legitimation, the central role of sensegiving and sensehiding in discursive legitimation, the inherently political nature of legitimation and the risks associated with politicization, the special problems associated with fashionable discourses and the role of the media, the use of specific discursive strategies for legitimation and delegitimation, and the crucial role of actual integration results. This analysis adds to the existing research on mergers and acquisitions by treating discursive legitimation as part of the merger dynamics. In particular, our case analysis provides a new explanation for merger failure. We also believe that the recursive model connecting discursive legitimation and delegitimation strategies to concrete organizational action makes a more general contribution to our understanding of organizational legitimation.

Key words: merger; acquisition; discourse; legitimacy; legitimation; integration History: Published online in Articles in Advance.

Despite extensive research on mergers and acquisitions, we do not seem to fully understand the dynamics of postmerger integration. In particular, there is a paucity of knowledge on the pathological dynamics that often lie behind merger failure. We argue in this paper that one of the missing pieces of the puzzle is the central role of legitimation in merger processes. Legitimation is an essential prerequisite for the concerted action 
needed to reap the benefits of potential synergies. However, "selling speeches" frequently produce unrealistic expectations about synergies and lead integration efforts astray. Moreover, integration efforts often result in unanticipated outcomes and new assessments of the meaning and legitimacy of the merger or acquisition. We maintain that it is useful to view legitimation as intimately linked with postmerger decision making, not merely as a first step in integration project management. In particular, we argue that there is a need to focus on the recursive relationship between discursive legitimation and organizational action in merging organizations. We see this recursive relationship as a key dialectic in mergers and acquisitions. Its analysis helps us to understand the emergence of unanticipated problems and challenges in the course of organizational integration.

Few studies have examined the social processes through which mergers and acquisitions are legitimated. Exceptions include studies on announcements of merger decisions (Demers et al. 2003) and analyses of media coverage (Tienari et al. 2003, Comtois et al. 2004). Our analysis builds on these studies but attempts to go further by linking discursive legitimation with organizational action in merging organizations. Thus, the aim is not to focus only on separate instances of corporate communications or media discussions, but to view discursive legitimation as an inherent part of unfolding merger processes.

In line with previous studies, we see legitimacy as a socially constructed sense of appropriateness (Luckmann 1987, Suchman 1995). We focus on the discursive aspects of legitimacy and the discursive strategies used to establish or resist legitimacy (Suddaby and Greenwood 2005, Vaara et al. 2006). This allows us to shift attention from established senses of legitimacy to the actual legitimation processes. We adopt a critical discursive perspective (Phillips and Hardy 2002, Fairclough 2005) that helps us to see how discursive strategizing is part of organizational politics and power plays in and around merging organizations. Furthermore, this approach allows us to place discourses and discursive events in the wider organizational context, as part of the unfolding events in changing organizations.

Our objectives are twofold: (1) to outline a general theoretical model that helps us understand the dynamics of discursive legitimation and organizational action in unfolding merger processes and (2) to distinguish the pathological tendencies that often plague 
postmerger integration. In our theoretical model, we conceptualize discursive legitimation as an inherent part of the dynamics of merger or acquisition processes, and we advance a recursive perspective on action and discourse that focuses attention on the unintended consequences of the legitimation dynamics. Our empirical analysis concentrates on the merger between the two French pharmaceutical companies BioMérieux and Pierre Fabre. This "revealing" case serves to test our theoretical model of discursive legitimation and to develop understanding of the pathological organizational dynamics that often lie behind merger failure. The merger was announced in September 2000, and by the summer of 2002 it had already broken up. The primary justification for the merger was the potential for synergy from the combination of pharmaceutical therapy and diagnostics, expressed in the pseudoscientific concept "theranostics."

This paper is structured as follows. Next, we review existing research on mergers and acquisitions and organizational legitimacy. This paves the way for our critical discursive perspective and theoretical model. We then focus on the merger between BioMérieux and Pierre Fabre. Based on a multimethod critical analysis of extensive material, we highlight specific discursive and sociopolitical dynamics in legitimation. The case analysis leads to a discussion of the risks and problems linked with discursive legitimation. We conclude by summarizing our key points and by suggesting avenues for future research. 


\section{Recursive Perspective on Discursive Legitimation}

\section{Prior Studies on Mergers and Acquisitions}

Studies on mergers and acquisitions have rarely focused on "legitimacy" but provide important insights into how specific ideas are justified and legitimated in this context. Scholars examining merger motives have mostly focused on rational motives, but less legitimate motives have also received attention (Trautwein 1990). One of the most interesting ones is "empire building," according to which managerial decision makers, more or less intentionally, favor growth and expansion at the expense of shareholder value (Trautwein 1990, Seth et al. 2002). Subsequent failures have also been explained by managerial "hubris," that is, a tendency to be overenthusiastic and overconfident in merger or acquisition plans (Seth et al. 2002). Such explanations can be linked with "managerialism," that is, the practice of placing management's ideas and objectives above everything else (Seth et al. 2002). Another interesting perspective links mergers and acquisitions with social movements and "fashions" (Davis 1994, Thornton 1995). Accordingly, decision makers tend to follow the trends and fads of the moment without always being able to critically evaluate the projects. Interestingly, actors such as industry experts, investment bankers, and consultants play a central role in these processes (Lubatkin and Lane 1996). Rather than being "neutral" actors, they often have vested interests in promoting specific ideas and fashions.

Scholars looking at acquisition decision making have pointed to cognitive simplifications and behavioral tendencies that often lead to unrealistic ideas about the merger benefits. These tendencies include escalating momentum and increasing commitment, meaning that the decision makers involved find it increasingly difficult to let go of initial ideas (Duhaime and Schwenk 1985, Jemison and Sitkin 1986, Haunschild et al. 1994, Coff 2002). They can be linked with "groupthink" (Janis 1972), that is, an increasing focus on specific ideas to the extent that it impedes critical thinking. Furthermore, as decision makers are often forced to "sell" their ideas to others, inflated and ambiguous expectations concerning the benefits of the deals sometimes arise (Jemison and Sitkin 1986). The secrecy usually involved in merger and acquisition 
processes and the pressure caused by tight schedules also contribute to the abovementioned tendencies (Jemison and Sitkin 1986, Coff 2002).

Other researchers have focused on postmerger integration. Studies looking at the strategic (Haspeslagh and Jemison 1991, Larsson and Finkelstein 1999, Schweizer 2005, Puranam et al. 2006, Shaver 2006), human resource (Buono and Bowditch 1989, Schweiger and DeNisi 1991, Greenwood et al. 1994), cultural (Olie 1994, Gertsen et al. 1998, Lubatkin et al. 1998, Stahl and Mendenhall 2005), and political (Hambrick and Cannella 1993, Vaara 2003, Paruchuriet al. 2006) aspects have all pointed to the complex and unpredictable nature of these processes. In particular, the initial ideas or plans concerning synergy or value most often have to be modified and new justifications developed (Haspeslagh and Jemison 1991). At the same time, various kinds of problems related to organizational resistance (Buono and Bowditch 1989), cultural incompatibilities and clashes (Cartwright and Cooper 1993, Stahl and Mendenhall 2005), and politicking (Vaara 2003) tend to emerge as organizational and managerial challenges. In these processes, communication is often seen as a crucial managerial activity through which plans and actions can be explained and justified (Bastien 1987, Schweiger and DeNisi 1991).

Some studies have examined the legitimation of mergers and acquisitions in official announcements. Demers et al. (2003) took a narrative perspective on the legitimation of changes in the merger and acquisition context. They examined texts as "wedding narratives." Their results showed that the legitimating narratives can be based on very different foundations - tradition, meansends rationality, charisma, or value rationality - and involve different discursive and narrative means. Other studies have analyzed media coverage around mergers and acquisitions. These studies have shown how the media constructs certain kinds of images of mergers and acquisitions, thereby forming an important arena for the legitimation of these deals (Hirsch 1986, Schneider and Dunbar 1992, Hellgren et al. 2002, Kitchener 2003, Tienari et al. 2003, Comtois et al. 2004, Leonardi and Jackson 2004). On one hand, the media can pick up specific issues and thus promote or question the legitimacy of the merger or acquisition (Hellgren et al. 2002, Comtois et al. 2004, Leonardi and Jackson 2004). On the other hand, the actors 
involved can also use the media as an arena for "discursive strategizing," that is, for arguing over the legitimacy or illegitimacy of specific ideas or plans (Tienari et al. 2003).

As a result of these and other studies, we have important insights as to how legitimacy is established in mergers and acquisitions. However, the fact remains that we lack an in-depth understanding of how legitimation efforts are linked with organizational actions in actual integration processes.

\section{Legitimation in Organizational Analysis}

Legitimacy has been a central theme in sociological analysis ever since Weber (1947). It is a concept that is closely linked with other key social and political terms such as authority, power, and ideology (Berger and Luckmann 1966, Habermas 1975, Giddens 1984, Luckmann 1987). In the organizational context, legitimacy has usually been seen as an inherent part of organizational stability and change (Scott 1995, Suchman 1995, Deephouse 1996, Kostova and Zaheer 1999, Ashforth and Gibbs 1990, Phillips et al. 2004). Following this tradition, we adopt a broad definition of legitimacy: "a generalized perception or assumption that the actions of an entity are desirable, proper, or appropriate within some socially constructed system of norms, values, beliefs, and definitions" (Suchman 1995, p. 574).From this perspective, legitimacy is a fundamental social phenomenon that links an organization, a specific change such as a merger or an acquisition, and the authority of particular actors such as change agents together; justification refers to a rationale given for a particular change such as a merger or acquisition.

Previous studies have shown that legitimacy can rest on different bases: the pragmatic, meaning calculations involving self-interest; the moral, based on normative approval; and the cognitive, based on comprehensibility and taken-for-grantedness (Suchman 1995). Scholars have also pointed out that unexpected or controversial actions - such as mergers and acquisitions - create a particular need to negotiate and reestablish legitimacy (Kostova and Zaheer 1999). These analyses have shown how the legitimacy of the whole organization is closely linked to the legitimacy of such changes (Hardy and Phillips 1998, Kostova and Zaheer 1999). In many cases, dramatic changes 
can in fact constitute legitimacy crises where the future of the organization is at stake (Kostova and Zaheer 1999).

Importantly for our analysis, studies have paid attention to the discursive aspects of legitimation. Researchers have shown how impression management is a central part of legitimation (Elsbach and Sutton 1992, Elsbach 1994, Arndt and Bigelow 2000, Brown and Jones 2000). Scholars have demonstrated that organizational spokepersons use specifics tactics to establish legitimacy (Staw et al. 1983, Elsbach and Sutton 1992, Elsbach 1994). They have also illustrated how discursively established legitimacy is linked with identity construction and stakeholder relations (Hardy and Phillips 1998). In addition, attention has been paid to the central role of legitimating accounts and the ways on which actors frame issues (Creed et al. 2002). Others have then singled out specific elements in rhetorical justification (Martin et al. 1990, Demers et al. 2003, Green 2004, Suddaby and Greenwood 2005, Vaara et al. 2006). In all, a discursive approach allows one to shift attention from established legitimacy to the discursive sensemaking processes through which legitimacy is established. In the following, we outline a critical discursive approach that enables us to focus on the dynamics of discursive legitimation and its relation to organizational action in the context of mergers and acquisitions.

\section{Critical Discursive Approach to Legitimation}

There are significant differences across discursive approaches in social science (van Dijk 1997) and organizational studies (Alvesson and Kärreman 2000, Phillips and Hardy 2002, Grant et al. 2004, Hardy et al. 2004). In this paper, we follow a critical discursive approach that centers on the role of discourse in the social construction of power relationships and social order (Phillips and Hardy 2002, Fairclough 2003). Accordingly, organizational rhetoric is not taken at face value but analyzed in a way that highlights underlying meanings and problematic organizational implications that easily pass unnoticed in more "neutral" analyses (Fairclough 2003). In particular, we adopt a critical realist position that allows us to view organizational discourses as part of other social and material practices (Reed 2004, Fairclough 2005). 
In this view, legitimacy is always established in relation to discourses that provide the "frames" with which people make sense of particular issues and give sense to them (van Dijk 1998, van Leeuwen and Wodak 1999). Legitimation is the creation of a sense of positive, beneficial, ethical, understandable, necessary, or otherwise acceptable action in a specific setting (van Dijk 1998, van Leeuwen and Wodak 1999). Delegitimation in turn means establishing a sense of negative, morally reprehensible, or otherwise unacceptable action or overall state of affairs (Rojo and van Dijk 1997, van Leeuwen and Wodak 1999). Delegitimation may thus be resistance to legitimation in situations such as merger announcements (Demers et al. 2003). However, legitimation and delegitimation are not always symmetrical processes. For instance, in their analysis of 20th century revolutions, Martin et al. (1990) showed that the delegitimation of the status quo and the legitimation of an alternative regime did not follow the same patterns. Notably, delegitimation involved more complex arguments than legitimation.

From a critical perspective, discursive legitimation deals with power and is inherently political in nature (Rojo and van Dijk 1997, van Leeuwen and Wodak 1999). Central here is the close linkage between the legitimacy of specific actions and the power positions of social actors (Rojo and van Dijk 1997). Accordingly, one can often distinguish sociopolitical struggles for legitimation and delegitimation (Rojo and van Dijk 1997, Vaara et al. 2006). Thus, legitimation involves more or less conscious discursive strategizing. For example, Tienari et al. (2003) demonstrated how discursive strategizing often implies a need to link the arguments to metadiscourses that are generally approved and promoted in society. Their analysis showed how actors such as corporate managers drew on global capitalist and nationalistic discourses to legitimate or delegitimate the selling off of a nationally owned bank. The analysis illustrated that the same actors mobilized different- even contradictory-discourses at different points in time.

Legitimation involves "sensegiving" (Gioia and Chittipeddi 1991, Rouleau 2005, Fiss and Zajac 2006) but also "sensehiding." Thus, the discourse can be mobilizing in terms of promoting a specific kind of thinking and action or manipulative in terms of hiding particular ideas. At the micro-level, actors make use of discursive strategies to legitimate mergers and acquisitions. Suddaby and Greenwood (2005) singled out five 
rhetorical strategies used to legitimate a new kind of organizational combination: teleological, historical, cosmological, ontological, and value-based strategies. In their analysis of a controversial cross-border merger, Vaara et al. (2006) distinguished normalization, authorization, rationalization, moralization, and narrativization as central strategies through which senses of legitimacy or illegitimacy were created. We shall build on this model in our empirical analysis.

Although actors may thus purposefully promote specific views, they are also affected by and operate with the available discourses. We are all constrained by discourses to the extent that we are not aware of their pervasive role in organizations or society at large (Foucault 1994). Importantly, specific discourses seem to provide a more natural basis for legitimation than others if they conform to the prevailing norms and values (van Dijk 1998). Particular justifications - that is, specific ways of legitimation by particular discourses - are more appealing or fashionable than others. In contemporary mergers, "synergies" created by integration tend to play an accentuated role. What is special about these justifications is that they are by nature "imaginary," that is, things that are being talked into being (Fairclough and Thomas 2004).

In contemporary society, legitimation processes take place in various social arenas. Experts may play a central role in the justification of merger decisions or subsequent changes. Interestingly, their position is often far from "neutral," as in the case of consultants or investment bankers (Lubatkin and Lane 1996). Journalists can also exercise significant power in legitimation. They often reinforce existing ideas and interpretations in their capacity as gatekeepers and editors of information flows (Parsons 1989). Bourdieu (1998) talks about "commonplaces": it is frequently in the media's interests to reproduce what the audience wants to hear. However, at times, journalists can also act as critical observers as in investigative journalism (Doyle 2006). In all, journalists seem to play varied roles in promoting or downplaying specific discourses, warranting voice to specific concerns or silencing them (Kjaer and Slaatta 2007). This is also the case with mergers and acquisitions (Comtois et al. 2004, Vaara et al. 2006).

Legitimation attempts lead to established legitimacy if and only if the specific ideas and discourses are "consumed"; that is, key stakeholders must internalize the discourse in question (Hardy and Phillips 2004). Hardy et al. (2000) have described 
discourse mobilization as a process involving circuits of activity, performativity, and connectivity. First, in circuits of activity, discursive statements are introduced to evoke particular meanings. Second, such discursive actions must intersect with circuits of performativity; it must engage other actors. Third, when these two circuits intersect, connectivity occurs, and discursive statements "take." This kind of perspective forms the basis of our analysis, but we emphasize the recursiveness of discourse and action: actions require legitimation, and legitimation leads to new action.

Discursive legitimation has important organizational implications in mergers and acquisitions. We underscore three kinds of dynamics. First, the justifications provided for the legitimation of the merger serve as the primary frame for future actions. This is especially the case with integration, where attention usually focuses on those areas that are seen as the most central. Second, when specific ideas and justifications are institutionalized, they serve as important sensemaking frames in the postmerger organization. The justifications are linked with success/failure evaluations and ultimately the very identity of the new organization. Third, the legitimation process also deals with the power position of actors such as the architects of the merger and the new corporate management. In particular, the overall sense of success/failure tends to have strong implications for the authority of those seen as responsible for the merger or specific integration efforts. We can thus see how discursive legitimation is intimately linked with the integration efforts, the evaluation of success/failure, and the power position of the social actors.

This leads to a view where legitimation is not a separate issue but an inherent part of the dynamics of merger processes. Figure 1 provides a crude summary of the legitimation dynamics in an unfolding merger processes. The recursiveness of action and discourse is an essential part of the merger process: initial action (merger)legitimation - organizational mobilization (integration)-legitimation-future action. However, the discursive processes are also strongly influenced by available discursive resources, which provide specific means for sensemaking around the case in question. Furthermore, all organizational action is related to material reality. On one hand, organizational action has change implications, for example, in creating synergies. 


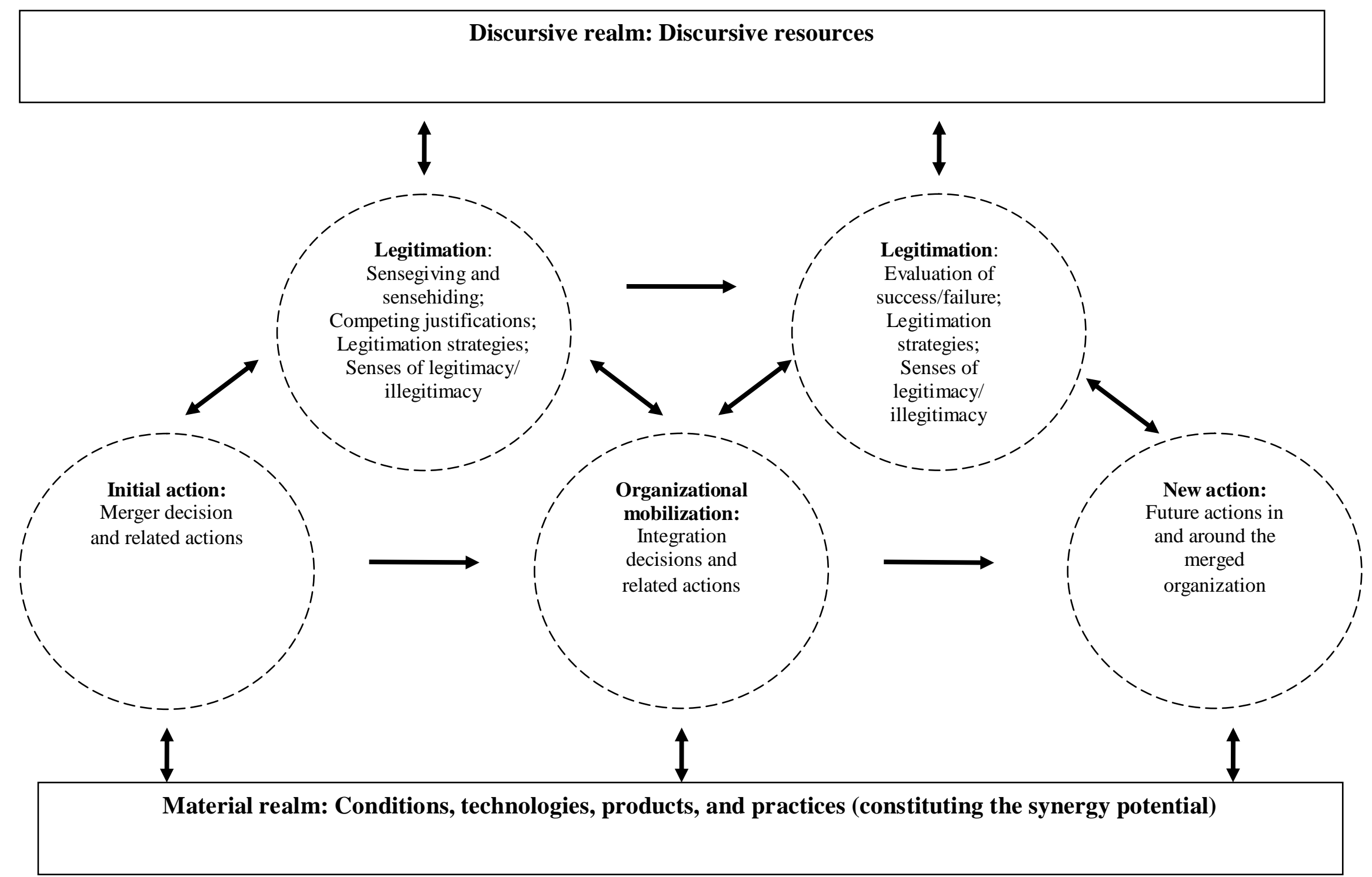

Figure 1: A recursive view on discursive legitimation and organizational action in mergers and acquisitions 
On the other hand, things such as existing products, technologies, processes, and practices greatly constrain the ability to create specific synergies.

\section{Biomerieux-Pierre Fabre as a Revealing Case}

Our study is based on an in-depth analysis of the merger between BioMérieux and Pierre Fabre (BMPF). This revealing case is used both to test the theoretical model of discursive legitimation and to further develop our understanding of pathological dynamics in postmerger integration. The BMPF merger is a "critical" case in the sense that it serves to "confirm, challenge, or extend the theory" (Yin 2005, p. 40) and "permits logical generalization" to other cases (Miles and Huberman 1994, p. 28). It is an "informationrich" case and thus especially suitable for theory testing (Patton 2002, p. 242). This is because the case was characterized by an intensive discussion in internal and external arenas. In particular, the rich debates around "theranostics" allow us to examine the role of various actors in these processes and their use of discursive strategies. The first discussions after the merger tended to predominantly legitimate the merger, and later events led to an intense delegitimating discussion. Thus, this case makes it possible to examine both legitimation and delegitimation dynamics as part of unfolding integration processes.

This case is also "revealing" in the specific inductive sense that it allows us to distinguish pathological tendencies (Tsoukas 1989, Pettigrew 1990). The case ended up in a break-up and thus provides a useful opportunity to specify processes that are likely to characterize other cases as well. The fact that the case involves "extreme situations," "critical incidents," and "social dramas" arguably makes it particularly suitable for longitudinal analysis (Pettigrew 1990, p. 275). The analysis of this case can thus lead to analytical generalizations: findings concerning mechanisms that on due reflection can be generalized beyond this particular case (Tsoukas 1989, Numagami1998).

BioMérieux is based in Lyon, where it was established by Alain Mérieux in 1963. In 1999, he was still the majority shareholder. BioMérieux was the eighth largest biological diagnostics company worldwide, with sales of EUR 0.5 billion, mainly in bacteriology, immunoessays, and molecular diagnostics (90\% of its turnover). 
BioMérieux was also a leading gene therapy firm: Transgène, its publicly traded subsidiary, develops gene therapy treatments and delivery technologies for cancer and cystic fibrosis.

Pierre Fabre is located at Castres. It was established in 1961 by Pierre Fabre. The company operates in pharmaceuticals, dermacosmetics, and homeopathy. In these activities, Pierre Fabre holds leading positions in Europe and internationally. The publicly traded subsidiary Dolisos makes natural herbal remedies. Consolidated sales reached EUR 1.1 billion in 1999, 40\% of which were outside of France. Pierre Fabre's R\&D focuses on four major therapeutic areas: oncology, immunology, the central nervous system, and the cardiovascular system. Their immunology research center (CIPF) is known worldwide, and at the time of the merger two cancer vaccines were under stage III clinical trial.

The intent to merge was announced on September 20, 2000. A key justification was the synergy potential related to the combination of pharmaceutical therapy (Pierre Fabre) and diagnostics (BioMérieux), combined in the term "theranostics." This idea was discussed widely in the media, and the merger was seen as a forerunner in modern pharmaceutics. At the end of 2000, the shareholders' meetings officially approved the merger. Pierre Fabre was appointed president of the advisory board, and Alain Mérieux became president of the directory board. Otherwise, top management positions were divided between the two companies. The merger started with a positive atmosphere and was strongly supported by the internal and external stakeholders. Integration began with visits between representatives of both sides and an exchange of personnel. Seven groups were formed to uncover and realize synergies, but their approach remained cautious. Conflicts started to emerge during the second quarter of 2001. At this point, it became clear that the views concerning future strategies as well as the potential synergies were very different. In early 2002 , rumors about a potential break-up spread. The founders and their closest collaborators became convinced that the merger did not make sense; there was little if any synergy to be realized. In June 2002, the breakup was made official by the shareholders' meetings. 
Methodology: Critical Multimethod Approach

In our case analysis, we concentrated on the problematic aspects and implications of discursive legitimation: how legitimacy and illegitimacy were constructed through specific discursive strategies and how these discursive constructions were linked with organizational action and the interests of particular actors. Even though we adopted such a critical approach, we were fortunate to be given consent to carry out this research project and gain access to the case immediately after the break-up. Accordingly, we could interview managers and other organizational members and examine all kinds of company and public material. However, this did not apply to the owners, who have a policy of not commenting on any business transaction. Throughout this research project, we have been very conscious of the ethical concerns in conducting a critical analysis. In our analysis, we have also been careful to protect the anonymity of specific informants, especially those whose actions have not been scrutinized in public. We are privileged to be able to publish the case without using pseudonyms. This is rare in critical organization studies but adds to the validity of our analysis and enhances the prospects for learning from this case.

Our analysis builds on a multimethod approach. We sought to reveal essential discursive and social dynamics by using several complementary sources of data and methods of analysis. This kind of strategy is recommended for case studies that intend to reconstruct actual processes and events (e.g., Langley 1999). Such a strategy can be seen as particularly fruitful for organizational discourse analysis, examining not only discourse per se, but also the social conditions and practices with which the discourses are intimately linked (Phillips and Hardy 2002, Hardy et al. 2004). Accordingly, we gathered extensive data and conducted a multifaceted analysis of the discursive legitimation processes. Our methods included a qualitative analysis of the organizational sensemaking processes (based primarily on interviews, informal encounters, and company documents), a content analysis of the media coverage (extensive media material), an historical analysis of the evolution of the "theranostics" discourse (historical data, media texts, and interviews), an analysis of the social practices of communications experts and journalists in their reporting on this topic (interviews), and a critical discourse analysis of the 
legitimation strategies around theranostics (interviews, company documents, communications material, and media texts).

A key part of our analysis was a qualitative analysis of organizational sensemaking, that is, how managers and other organizational members viewed and discursively made sense of the merger, integration work, and break-up. This part of the analysis resembles a classical case study in that we first mapped out key events and decisions in great detail (e.g., Langley 1999) and then focused on organizational members' sensemaking patterns. In this analysis, we drew from interviews with organizational members and various kinds of company documents. We interviewed 15 managers working for BMPF, or associated with it, in the spring of 2003. They included five top managers, seven middle managers, and project leaders working on corporate communications and integration, and three high-level associates in consulting firms working closely with BMPF. These interviews were semistructured and concentrated on organizational sensemaking, decision making, communication, and internal politics. We ran five additional interviews in the fall of 2004 to complement our understanding. We had also the opportunity to meet several times with organizational members informally to verify our interpretations. Further, we gathered all the available internal material concerning the merger process and integration work. This included partial access to internal documents for the seven "synergies" groups working on integration projects.

Based on all this material, we identified patterns in organizational sensemaking and significant changes in the way mergers in general and theranostics in particular were seen over time. In particular, we were able to reconstruct how organizational members' first ideas of the merger had been influenced by theranostics, how this discourse was used in legitimation, how the integration efforts were planned and affected by theranostics, how views about theranostics changed as a result of disappointments in integration projects, how theranostics became a symbol of failure, how this led to a legitimacy crisis, how the idea of break-up gained ground, and how the break-up was then legitimated by different arguments in various arenas.

To be able to understand the wider discussion around this merger, we conducted a thematic content analysis of the media coverage. 
Table 1 - Content analysis

\begin{tabular}{|c|c|c|c|}
\hline Categories & $\begin{array}{c}\text { Year 2000* } \\
(\mathrm{n}=40)\end{array}$ & $\begin{array}{c}\text { Year 2001* } \\
(\mathrm{n}=26)\end{array}$ & $\begin{array}{c}\text { Year 2002* } \\
(\mathrm{n}=41)\end{array}$ \\
\hline Governance (legal aspects; relations to shareholders; etc.) & $24(60 \%)$ & $5(19 \%)$ & $23(56 \%)$ \\
\hline Merger type (preservation type: autonomous firms; offensive synergies; no employment threats) & $6(15 \%)$ & $5(19 \%)$ & $11(27 \%)$ \\
\hline Attractiveness of the new group to negotiate partnerships \& acquisitions & $6(15 \%)$ & $4(15 \%)$ & \\
\hline Announcement of partnerships \& acquisitions & & $15(58 \%)$ & \\
\hline Synergies related to the convergence between Diagnostic \& Therapy (theranostics) & $12(30 \%)$ & $2(8 \%)$ & \\
\hline Synergies related to the combination between CIPF and Transgène (immunology) & $2(5 \%)$ & & \\
\hline Absence of synergies (of both types) & & & $13(32 \%)$ \\
\hline Merger as answer to succession issue $\&$ alternative to immediate listing on the stock exchange & $5(12.5 \%)$ & $5(19 \%)$ & \\
\hline Return to former issues of succession (Pierre Fabre) or public listing (BioMérieux) & & & $11(27 \%)$ \\
\hline Personal relations between the founders \& similarities between their personalities & $3(7.5 \%)$ & & \\
\hline Power conflicts among founders or top executives and differences between personalities & & & $15(37 \%)$ \\
\hline Cultural (organizational) differences between the companies & & & $3(7 \%)$ \\
\hline Diverging strategies & & & $13(32 \%)$ \\
\hline
\end{tabular}

*Total greater than $100 \%$ due to multiple themes in specific articles. 
We first collected a database of hundreds of articles with "BioMérieux" or "Pierre Fabre" as a keyword in the title or text. We then focused on a sample of 107 articles involving arguments relevant for our analysis of legitimation: 55 articles in the leading business dailies in France (Le Figaro, Les Echos, La Tribune, and L'Usine Nouvelle), 20 articles in the international press (Wall Street Journal, Herald Tribune, and Reuters), and 32 articles in the regional press (Le Progrès in the BioMérieux headquarters region; La Dépêche $d u$ Midi \& Midi Presse in Pierre Fabre headquarters region). Forty were published during the announcement phase, in the fourth quarter of 2000; 26 were published in 2001; and 41 were published during the first part of 2002 when the break-up was announced. Key themes emerged from repeated reading of the material. Multiauthor coding provided a basis for a robust category design. Some categories were relevant throughout the case (e.g., governance and merger type), and others appeared only in the second (announcement of partnerships and acquisitions) or third period (return to former issues of succession or public listing). The key results are summarized in Table 1. It should be noted that governance and merger type are general issues that are most often discussed in reporting on mergers and acquisitions; hence their frequent occurrence is not surprising. Although synergies related to the convergence between diagnostic and therapy was an explicit key theme in $30 \%$ of the reports during the first period, it was an underlying theme in most other texts. Similarly, absence of synergies was an explicit theme in $32 \%$ of the texts but an implicit one in many other texts (especially in those dealing with "power conflicts" and "divergent strategies"). It is this central role of the "theranostics" theme that made us focus on this discourse in the subsequent analyses.

We also examined the emergence and evolution of the theranostics concept based on extensive data on diagnostics and therapy that included a large number of industry reports and expert interviews. In this analysis, we focused on the diffusion, translation, and recontextualization of this discourse. This historical analysis showed how "theranostics" emerged out of the more general discourse on the "convergence" of diagnostics and therapy, how it was coined by a consultant, and how it spread into pharmaceutical companies and industry magazines and was eventually picked up by a French journalist and top management of BMPF. The appendix provides a summary of this analysis. 
We complemented the previous analyses with interviews of columnists and investigative journalists in the four leading French business dailies. These interviews advanced our understanding of the nature of the reporting at specific time points as well as the concrete linkages between company communication, internal discussions, and journalistic reporting. For example, a particular argument could be developed by corporate executives for use in corporate communications and then reproduced in the media coverage. Similarly, sometimes a statement originally made in the media was adopted inside the company, and so forth. Rather than simply describing what was said and written by whom, we examined the actions of the communication experts and journalists through a critical lens-how their choices reflected their interests (e.g., "selling a specific message" or "pleasing" particular stakeholders) and how these choices led to an overemphasis on specific ideas and silencing of other perspectives.

Finally, we carried out a critical discursive analysis (Fairclough 2003, Wodak 2004) of the legitimation strategies used. In this crucial part of our study, we analyzed the explicit or implicit discursive means that were used more or less intentionally for legitimation or delegitimation purposes. In this analysis, we concentrated on the discussions around "theranostics." We first searched for typical patterns in the interviews, the company documents, the communications material, and the media texts. The previous sensemaking, content, and communication practice analyses helped us to place specific messages and arguments in context, that is, to distinguish important texts and communications from less important ones. By drawing on previous studies (van Leeuwen and Wodak 1999, Suddaby and Greenwood 2005, Vaara et al. 2006), we concentrated on identifying characteristic legitimization strategies of the key actors. In particular, we used the theoretical model of Vaara et al. (2006) as the basis for our coding ("normalization," "authorization," "rationalization," "moralization," and "narrativization"). However, when proceeding with the analysis, we modified these categories so that they would best fit our empirical material. This led us to distinguish and elaborate on the following legitimation and delegitimation strategies: "(de)naturalization" (rendering something natural (unnatural) by specific discursive means), "rationalization" (providing specific rational arguments to establish legitimacy), "exemplification" (using specific examples to establish legitimacy), "authorization" (references to authorities), and "moralization" 
(establishing legitimacy by moral arguments). We recoded the material accordingly. We then conducted a closer analysis of illustrative textual examples, as is usually done in critical discourse analysis (Fairclough 2003). As a result, we exemplified typical strategies and their characteristic discursive features in the discussions around theranostics, summarized in Tables 2 and 3.

As is usually the case with discourse analysis, our approach was "abductive," involving a constant movement back and forth between theory and empirical material (Dubois and Gadde 2002, Wodak 2004). Accordingly, our analysis proceeded in stages where specific theoretical ideas were developed alongside increasingly accurate mapping of this case. In our multimethod approach, specific analyses complemented each other. In particular, the analysis of organizational sensemaking formed a basis for subsequent discursive analyses, but the other analyses also refined our understanding of the organizational sensemaking patterns. Further, informal discussions with the company representatives played an important role in the verification of our findings. This analysis finally resulted in a detailed mapping of the legitimation dynamics and the distinguishing of pathological patterns, as summarized in the next sections.

\section{Discursive Legitimation in BioMérieux-Pierre Fabre Merger}

This section provides an episodic description of discursive legitimation in the BMPF case following our theoretical model: (1) action: the merger decision; (2) legitimation: legitimation of the merger; (3) action: organizational mobilization for integration; (4) legitimation: the internal legitimacy crisis; (5) action: the breakup decision; and (6) legitimation: legitimation of the break-up.

\section{Action: Merger Decision}

The founders of BioMérieux and Pierre Fabre decided to consider joining forces in the beginning of 2000. They were friends and both involved in the French right-wing party. According to our interviews, they shared common values about the role of family-owned businesses and also concerns about the "short-termism" of financial markets. 
Table 2 - Legitimation strategies after the announcement of the merger (regarding theranostics)

\begin{tabular}{|c|c|c|c|}
\hline Type & Typical strategy & $\begin{array}{c}\text { Characteristic discursive } \\
\text { features }\end{array}$ & Examples \\
\hline Naturalization & $\begin{array}{l}\text { Inevitability of } \\
\text { convergence: moving } \\
\text { towards pharmaceuticals } \\
\text { adapted for specific patient } \\
\text { profiles }\end{array}$ & $\begin{array}{l}\text { Naturalizating elements } \\
\text { (trend, force) } \\
\text { Modality: necessity } \\
\text { Lack of criticism }\end{array}$ & $\begin{array}{l}\text { Internal discussion: "Alain Mérieux had a dream, not to say a fantasy, to relate diagnosis and therapy. This } \\
\text { means a new business model in the health industry." (Scientist from BioMérieux). } \\
\text { Initial press release: "Current trends are to combine diagnostics and therapeutics in order to meet the } \\
\text { growing demand of doctors and patients." (September 20" } 2000 \text { ). } \\
\text { Media: Frequent reproduction of the same or similar view in the media. }\end{array}$ \\
\hline Rationalization & $\begin{array}{l}\text { The immense future } \\
\text { market } \\
\text { Scientific rationale } \\
\text { (pseudo-scientific appeal) }\end{array}$ & $\begin{array}{l}\text { Factualization of future } \\
\text { benefits } \\
\text { Quantification } \\
\text { Lack of alternative } \\
\text { scenarios } \\
\text { Scientific (medical) } \\
\text { terms }\end{array}$ & $\begin{array}{l}\text { Media: Frequent references to immense future market, various areas of application, and the business } \\
\text { potential. E.g.: "Clinica Reports is convinced about the growing impact of theranostic solutions on the } \\
\text { worldwide market for diagnostics ( } 19 \text { billion dollars in 1999) within five years." (Les Echos, } 1^{\text {st }} \text { December } \\
\text { 2000). } \\
\text { Internal discussion: According to the interviews, frequent discussion on the great business opportunities. } \\
\text { Initial press release: "Progress in genomic research ... leads to a renewed understanding of the fundamental } \\
\text { origins of diseases, to new generations of diagnostic tests and treatments, and paves the way to a true } \\
\text { personalization of treatments." (September } 20^{\text {th }}, 2000 \text { ) (the argument repeated in the media) } \\
\text { Internal discussion: "I had the feeling that theranostics widened the scope of what we call pharmaco- } \\
\text { genomics" (Top manager at BioMérieux). }\end{array}$ \\
\hline Exemplification & $\begin{array}{l}\text { Examples of other } \\
\text { companies }\end{array}$ & $\begin{array}{l}\text { Explicit and implicit } \\
\text { references to successful } \\
\text { companies } \\
\text { Lack of contrary } \\
\text { examples }\end{array}$ & $\begin{array}{l}\text { Media: "While many companies do not yet develop theranostic approaches, other companies such as Roche } \\
\left.\text { or Abbott make it a strategic axis." (Les Echos, December } 1{ }^{\text {st }}, 2000\right) \text {. } \\
\text { Internal discussion: According to interviews, Roche was frequently used as the example for success in } \\
\text { theranostics. }\end{array}$ \\
\hline Authorization & References to authorities & $\begin{array}{l}\text { Explicit references to } \\
\text { experts, researchers, } \\
\text { consultants, and research } \\
\text { reports }\end{array}$ & $\begin{array}{l}\text { Media: Frequent references to various experts, research reports, and consultants. Bélingard (former CEO of } \\
\text { Roche Diagnostics Division (1990-1998)) is given a special authority position. } \\
\text { Internal discussion: "Jean-Luc Bélingard had been the CEO of Roche Diagnostiques. He had negotiated the } \\
\text { acquisition of Boehringer Mannheim, a German diagnostic company. This outstanding, profitable } \\
\text { acquisition improved Roche's strategic position, and the paradigm according to which diagnostics and } \\
\text { pharmaceuticals would increasingly converge. One simply trusts Bélingard, a great expert in synergies } \\
\text { between pharmaceuticals and diagnostics." (Top manager) }\end{array}$ \\
\hline Moralization & $\begin{array}{l}\text { Moral basis in better and } \\
\text { less expensive treatment }\end{array}$ & $\begin{array}{l}\text { Explicit and implicit } \\
\text { references to a 'higher } \\
\text { purpose' }\end{array}$ & $\begin{array}{l}\text { Media: "The convergence between diagnostics and therapy should contribute to reduce bealth expenses, though } \\
\text { not necessarily in the short-term, as intense research could increase price treatments, and diminish the odds that } \\
\text { existing blockbusters - one fits all medicaments - burt patients." (IBM Global Services } 2002 \text { Report on the "Future } \\
\text { of the Pharmaceutical Industry"). } \\
\text { Internal discussion: "This is the anti-blockbuster model. It is widely estimated that in } 60 \% \text { of the cases, the } \\
\text { patients who receive blockbuster drugs are not [affected], or are even adversely affected, for a number of } \\
\text { reasons." (Scientist at BioMérieux). }\end{array}$ \\
\hline
\end{tabular}


They saw the merger as a means to protect their "patrimonial interests from larger predators" and to postpone "definite decisions about successors." In addition, in the longer run, the idea of a possible public listing of the merged company attracted the leaders.

As the negotiations proceeded, the founders and the top managers focused increasingly on the strategic and operative benefits coming from the merger. "Synergy" became a means through which they could make sense of the benefits expected from the merger and give sense to them. Though individual people held different views about potential synergy, the negotiators tended to agree that there were at least three types of synergy to be exploited. First, there were financial synergies related to the ability to pool resources and "manage" the portfolio. An example was the possible divestment of some of Pierre Fabre's existing operations (homeopathy and/or dermocosmetics) to finance the further development of cancer research. Second, the top managers saw benefits coming from the ability to exploit the companies' networks. In particular, the idea of leveraging BioMérieux's international network to sell Pierre Fabre's products was attractive. Third, and most important, great potential was seen in combining the technological competences of the two companies. The combination of CIPF (immunology R\&D center of Pierre Fabre) and BioMérieux's Transgène was a thought-provoking idea. Also, the ability to create synergy out of the combination of pharmaceutical therapy (Pierre Fabre) and diagnostics (BioMérieux) knowledge and capabilities - later expressed by the term theranostics — rapidly gained ground.

\section{Legitimation: Legitimation of Merger}

According to our interviewees, the merger called for a "strategic" rationale, a story to be sold to external audiences and internal stakeholders alike. Among other alternatives, this idea of combining therapy and diagnostics emerged as the story that was most "sellable." A corporate communication executive described this as follows:

From June 2000, I was involved; we were 10 altogether. We were called to a meeting in Paris, in mid-June - we did not exactly know why - and there the founders announced that they would merge. Then, during the summer, we conducted studies and we wondered: What on earth will we be able to tell about this story? _ _ _We had brainstorming sessions, we built arguments for the press. Then the idea of allying diagnosis and treatment made sense _ _ _ _ At that time, a paper came out and mentioned this model of theranostics _ _ _ _ 

concept and the champion, we had a nice story to tell!

The combination of therapy and diagnostics thus became the official justification to be offered to the public. At the same time, this discourse served as a means of hiding the other, less legitimate motivations of the founders related to succession or public listing. Further, the focus on this discourse meant that other ideas concerning benefits were not clearly articulated when the merger was announced. This was the case in particular with the synergies related to the combination of BioMérieux's Transgène and Pierre Fabre's immunology center. When announcing the merger, the corporate communications thus focused on the combination of therapy and diagnostics. This was reflected in the initial press release written by the communication officers and the communications agency:

In an increasingly competitive and constantly changing environment, the merger of the two groups, which uphold strong traditions in pharmaceuticals and biologicals and share the same corporate culture, would make it possible to respond to new developments in the world of medicine. Current trends are to combine diagnostics and therapeutics in order to meet the growing demand of doctors and patients. BMPF would control the entire $R \& D$ process, as well as basic research and the marketing of diagnostic and therapeutic solutions _ _ _ _ BioMérieux chairman Alain Mérieux maintains that diagnostics and medicines are set to become increasingly closely linked. (September 20, 2000)

Three months later (December 21, 2000), when the merger had been officially approved, the press release featured the following heading: "Toward a medicine more adapted to each patient's profile, associating diagnosis, and therapy." The press releases illustrate the increasing focus on diagnostics and therapy. Although three "strategic interests" were mentioned in the first press release in September, by December there was only one: the combination of diagnostics and therapy. As to sensehiding, the first press release included three sentences on vaccine (combination of BioMérieux's Transgène and Pierre Fabre's immunology center), but in December this area was not mentioned at all. Immediately, the media picked up this discourse and hence reinforced its justificatory power. Florence Bauchard, a journalist specializing in pharmaceuticals and diagnostics, played a central role. She introduced the concept of "theranostics" in France as an 
abbreviation of the combination of therapy and diagnostics. This is what she wrote in Les Echos (the leading French business journal) in December 2000:

Pharmacy: The promise of "theranostics." For the first time in November 1998, the Food and Drug Administration recommended administration of the anti-cancer treatment Herceptin by Genentech only to patients who had gone through a preliminary test of sensibility (HercepTest by Dako). According to the Clinica Reports company, this act forged the birth of "theranostics," a new discipline that combines therapy and diagnosis _ _ _ - While most big pharmaceutical players abandoned their diagnostic activities in the 90s, Abbott and Roche seem to follow this strategy _ _ _ This also holds for the French family companies BioMérieux and Pierre Fabre, which just decided to merge. (p. 36)

She had tracked down the origin of the concept in an industrial report Clinica Reports (2000). This report had, in turn, taken the concept from an American consultant, the first ever to use this term to promote his newly founded BioTech start-up in July 1998 (see appendix).

Overall, the media focused increasingly on the theranostics discourse. Our content analysis of the media coverage shows that theranostics was the second most important theme in the public discussion after obvious questions related to governance (see Table 1). Interestingly, alternative ideas about potential synergies received almost no attention in the public discussion. For example, the benefits relying on the combination of BioMérieux's Transgène and Pierre Fabre's immunology center were rarely discussed in the media (see Table 1).

Importantly, theranostics became also the term used within BMPF. In particular, people like JeanLuc Bélingard - a new Vice President coming from Roche - spoke for theranostics on the overall rationale for the merger. Our interviewees suggested that even many of the senior managers who had initially been somewhat skeptical vis-à-vis the key idea started to believe in its promise. An expert described this as follows:

For instance, $X$, a chemist who came from $Y$, did not understand this pharmaceutical business at all. At the beginning, he did not comment publicly on this theranostics strategy. He eventually started to take it up, and it seems to me that he was truly convinced. Even Alain Mérieux, who did not seem very enthusiastic about it then, started to talk about it. 
Why did theranostics then become such a persuasive and convincing discourse? A critical discourse analysis of the internal and public discussion points to the frequent use of five powerful legitimation strategies: naturalization, rationalization, exemplification, authorization, and moralization (Table 2).

First, the convergence of therapy and diagnostics was naturalized. Theranostics was presented as an inevitable trend that companies should prepare for and make use of. This was a key part of the corporate communications, and the media spread and further reinforced this view. According to our interviews, this was also the spirit inside the organization when preparing for integration. In particular, top management team members promoted the view that this was the inevitable future in the industry.

Second, there were strong rational arguments that were repeated in company decision making, corporate communications, as well as the media. The future market was estimated to be immense. For example, in her initial article, Bauchard argued that the potential for theranostic treatments was almost unlimited and quoted figures from Clinica Reports that suggested that by 2005 theranostic treatment was taking a growing part of the $\$ 19$ billion annual market for diagnostic solutions. The concept of theranostics also had scientific appeal. Scientists and experts saw theranostics as an extension to the well-known scientific concepts of proteinomics (the analysis of DNA proteins) and pharmacogenomics (design of therapies and/or pharmaceutical products adapted to each single patient, based on DNA analysis). Consequently, the logic was difficult to challenge, especially by those organizational members who were not experts in pharmaceutics or diagnostics, to say nothing of outsiders.

Third, the appeal of the theranostics discourse was further reinforced by exemplification. Roche became a frequently cited example of a company focusing on a "theranostics" strategy. The recent revolutionary decisions by the U.S. Food and Drug Administration were also often mentioned in this context. Inside the merging organization, Roche became an ideal that the new BMPF should strive for.

Fourth, authorization was a major legitimation strategy. There were frequent references to experts, researchers, consultants, and research reports in the media coverage as well as in internal decision making. Interestingly, Bélingard emerged as a major authority figure both in the external and internal arenas. This was due to his experience in Roche but also because he was assigned a key role in the integration process.

Fifth, moralization was also an important part of the legitimation process. Both internally and in the media, theranostics was seen as a major means toward better and less expensive 
treatment for patients. Interestingly, it was specifically seen as an alternative to the blockbuster drugs manufactured by the world's largest pharmaceutical companies. As pointed out by the interviewees, such views gave "special meaning" to the merger and future integration.

\section{Action: Organizational Mobilization for Integration}

Top managers such as Bélingard promoted theranostics as the logic of action to be followed when integrating the operations of the two companies in early 2001. However, other actors also spread the theranostics discourse within the new group. Top management hired a special consulting company to aid in integration efforts, and the representatives of this company also focused on the theranostics concept and its organizational implications. Consequently, most of the integration efforts were designed to follow this logic. This was reflected in the work of the seven integration groups that were formed to uncover and realize synergies (Human Resources; Public Affairs; Legal Affairs; Communication; Purchasing; Finance; Business Development) as well as in R\&D. In most projects, it was the theranostics thinking that was the key objective. In particular, the theranostics discourse set great expectations concerning the combination benefits. Retrospectively, many of our interviewees referred to completely unrealistic expectations that seemed to be reinforced by the general enthusiasm around theranostics.

However, after the first concrete integration projects were launched, the managers and researchers in charge of specific tasks began to question these synergies. According to our interviews, project leaders first started to wonder whether the merger could really provide concrete synergies in the short or medium run. They pointed to the gap between the (long-term) scientific promise and the (short-term) financial means for implementing these synergies. There were also concerns related to the diagnostic part of theranostics. BioMérieux was engaged in diagnostic activities, but on the industrial level. Their current competences did not really cover genetic diagnostics, which was needed to develop combined theranostics products.

\section{Legitimation: Internal Legitimacy Crisis}

Gradually, organizational members started to view theranostic synergies as illusions from a scientific perspective. Their content and implications were debated internally as part of the various discussions around integration. One of the most experienced scientists at BioMérieux put it as follows: 
I had the feeling that at that time it was something floating in the air. The theranostic concept widened the well-known and scientifically sound pharmaco-genomics. I had never heard about theranostics before the merger. It was created from scratch for the needs of the merger. This concept provided the logic needed for it. It offered the advantage of credibility on paper, but in reality it does not work _ _ _ _ I guess that big consulting companies have worked very hard on developing this concept _ _ _ _ I don't want to talk about illusion, but I think that this is what top executives wanted to believe in.

It also became increasingly clear by mid-2001 that the people representing the two previously separate organizations had quite different views on the strategic and organizational implications of these synergies. This was the case especially with portfolio decisions, that is, the choices as to which businesses to keep and invest in. For instance, people from BioMérieux seemed to believe that focusing on theranostics meant implicitly that BMPF should divest the dermocosmetic and homeopathy businesses, which came from Pierre Fabre. An interviewee explained it as follows:

If they had really decided to pursue the convergence between diagnostics and therapy, this would have meant that Pierre Fabre had to get rid of all its businesses outside pharmaceuticals _ _ _ _ This obviously could not work! Asking Pierre Fabre to sell its dermo-cosmetic businesses - it was like clawing his eyes out! This could simply not be considered, given that one of his nephews manages these dermo-cosmetic businesses, and this nephew is the single family member in the company.

In this setting, the theranostics discourse served as a catalyst for revealing the differences in the views of the top decision makers when they started working on more concrete integration projects and had to make investment or divestment decisions. At the same time, the relations between the two merger parties became increasingly tense because of a constant battle over power. These tensions contributed to the politicization of the theranostics discourse.

Although the integration work focused on theranostics, little attention was given to the alternative synergies residing in the combination of BioMérieux's Transgène and Pierre Fabre's immunology center. During this time, a small group of consultants and scientists worked actively on this ambitious project, but the project was never given much attention within the merging 
organization. Apparently, top managers wanted first to focus on theranostics as the overall logic of the merger and therefore gave this other project less attention. Later, when the relationships between the key people deteriorated, it became clear that the project had not received sufficient political support to make it possible. In our interviews, several managers and project leaders openly regretted that the promising project was never given a chance.

Toward the end of 2001, top managers started to view the merger as a failure. In internal discussions, theranostics became a symbol of poor planning and failed integration. Disillusionment prevailed, the organization found itself in a legitimacy crisis, and the people that had been promoting the theranostics concept were increasingly criticized. Most notably, Bélingard, who had come to personify the theranostics discourse, was seen as the scapegoat. In fact, he eventually left the company at the end of 2001. The media did not, however, focus on these problems until the beginning of 2002. Their reporting concentrated mainly on new partnerships and smaller acquisitions conducted by the group (see Table 1).

\section{Action: Break-Up Decision}

Internally, corporate management started to look for ways to resolve the crisis. There were several alternatives, but the top managers found it difficult to agree on a new integration strategy that would have saved the corporation. Given the considerable disappointment concerning merger benefits and the deteriorated personal relationships, top owners and managers began to prepare for a break-up. In early 2002, rumors about the eventual break-up diffused. Les Echos was the first to suggest the possibility of a divorce (January 12, 2002). Three days later, the representatives of BMPF confirmed and openly admitted that there were "few synergies" to be found.

\section{Legitimation: Legitimation of the Break-Up}

Overall, the communication strategy of the two companies and their representatives was to avoid negative discussion around the break-up. Against this background, it is not surprising that the top managers and founders once again referred to synergies, but this time to their absence, to justify the break-up decision along the former organizational borders. This was apparently a useful way to avoid more elaborate public or internal scrutiny of the internal politics and managerial mistakes that could have challenged the legitimacy of the owners and the top managers of BioMérieux and Pierre Fabre. The ensuing discussion in the media was as much about the delegitimation of the 
merger as it was about the legitimation of the break-up. In addition to obvious reporting on changes in governance, the public discussion focused on three intertwined themes: absence of synergy, power conflicts, and divergent strategies (see Table 1). Thus, again, the central message of corporate communications — absence of synergy — was reinforced in the media.

A closer analysis of the discussion around the absence of synergy points to four frequently used discursive strategies: denaturalization, rationalization, authorization, and moralization (see Table 3). First, both the internal discussion and the media coverage tended to denaturalize the very idea of theranostics. Internally, people apparently focused more on the inability of BMPF to create such synergy, and the media condemned the very idea. What had previously been portrayed as an inevitable trend was now presented as wishful thinking. Such denaturalization involved strong emotional rhetoric, for example, pointing to "illusionary" thinking and "collective fallacies." Both the media reporting and the internal documents also used irony as a powerful rhetorical means to describe the "illusions" around theranostics.

Second, rational arguments for the lack of synergy were given both internally and in the media. This meant the reversal of the previous arguments in favor of theranostics. In the media, the discussion focused on the absence of synergy; internally some managers and scientists continued to believe in the promise of theranostics, but not in the case of BioMérieux and Pierre Fabre. According to our interviews, the internal discussion was characterized by disillusionment, where the ideals of theranostics were juxtaposed with the limited resources that the company had. In this discussion, these "facts" were often linked with strong emotional expressions, reflecting the depth of the collective disappointment.

Third, both internally and in the media, previous authorities were discredited. This involved criticism of the owners' decisions, but the discrediting focused on Bélingard. In fact, he became the culprit in the public discussion as well as internally. Inside the organization, his person and his actions were described in a very critical tone. Even our interviews included very strong emotional expressions. 
Table 3 - Delegitimation strategies used around the break-up (around the absence of synergy)

\begin{tabular}{|c|c|c|c|}
\hline Type & Typical strategy & $\begin{array}{c}\text { Characteristic discursive } \\
\text { features }\end{array}$ & Examples \\
\hline Denaturalization & $\begin{array}{l}\text { Denaturalization of } \\
\text { theranostics } \\
\text { Naturalization of break-up }\end{array}$ & $\begin{array}{l}\text { Critical tone } \\
\text { Use of irony }\end{array}$ & $\begin{array}{l}\text { Internal discussion: "It was phantasmagoria!" (Top manager). } \\
\text { Media: "Given the absence of synergies, it is natural for the companies to return from autonomy to } \\
\text { independence. Activities were too different to find bridges between them." (Le Figaro, May 17th, 2002). }\end{array}$ \\
\hline Rationalization & $\begin{array}{l}\text { Explanations for lack of } \\
\text { synergy }\end{array}$ & $\begin{array}{l}\text { Factualization } \\
\text { Emotional elements }\end{array}$ & $\begin{array}{l}\text { Internal discussion: "Neither Pierre Fabre nor BioMérieux have the structures and competences. They are in } \\
\text { the diagnostics business, yes, but it does not mean they can diagnose anything! BioMérieux is strong in the } \\
\text { field of industrial diagnosis, but very weak in the field of patient and/or DNA diagnosis. Only giants, in } \\
\text { partnerships with biotech start-ups, could do it" (Consultant working on the CIPF-Transgène project) } \\
\text { Media: "Of course, from an industrial point of view, Fabre and Biomérieux have nothing in common. The } \\
\text { first produces pharmaceutical and cosmetic products, the second diagnostic tests. Synergies could only be } \\
\left.\text { limited" (Les Echos, March } 27^{\text {th }}, 2002\right) \text {. } \\
\text { Media: "Financially, the two companies with very different businesses have not been able to calculate the } \\
\text { synergies expected from the merger. The height of absurdity was that experts from the two companies only } \\
\left.\text { started to work on calculations once the marriage was pronounced." (Le Figaro, May } 17^{\text {th }}, 2002\right)\end{array}$ \\
\hline Authorization & $\begin{array}{l}\text { Discrediting of previous } \\
\text { authorities }\end{array}$ & $\begin{array}{l}\text { Explicit and implicit } \\
\text { references discrediting } \\
\text { previous authorities } \\
\text { Emotional elements }\end{array}$ & $\begin{array}{l}\text { Internal discussion: "Jean-Luc Belingard was really the champion of the convergence. But in 2001, he } \\
\text { negotiated a number of small partnerships with small companies. And all of a sudden, we learnt that he was } \\
\text { also sitting in the advisory boards of these start-ups" (Top scientist at Pierre Fabre). } \\
\text { Internal discussion: "After Bélingard had left end of 2001, scientists and executives from CIPF who had } \\
\text { been cooperating with Biomérieux - I included- were being treated as scapegoats and invited to leave for } \\
\text { personal reasons" (Manager of CIPF). }\end{array}$ \\
\hline Moralization & $\begin{array}{l}\text { Questioning the moral } \\
\text { basis of theranostics } \\
\text { (hiding true motives) } \\
\text { New moral justifications } \\
\text { for the break-up }\end{array}$ & $\begin{array}{l}\text { Emotional elements } \\
\text { Critical tone } \\
\text { References to 'higher } \\
\text { purpose' }\end{array}$ & $\begin{array}{l}\text { Media: "The merger had no industrial sense. It was a marriage based on friendship above all." (Les Echos, } \\
\text { January 25th } 2002) \text {. } \\
\text { Internal discussion: "From my own personal feeling, it was rather a way to disguise, or rather to bring credit } \\
\text { to a purely patrimonial decision." (Top manager at BioMérieux). } \\
\text { Internal discussion/media: "For purely financial reasons, I did not want to be obliged to close down certain } \\
\text { sites, such as CIPF, or to sell some activities or brands. I simply could not accept this idea." (Comment of } \\
\left.\text { Pierre Fabre, in La Dépêche du Midi, August } 21^{\text {st }}, 2002\right) \text {. }\end{array}$ \\
\hline
\end{tabular}


Fourth, moralizations were also employed. There was increasing recognition both internally and in the media that theranostics was a way of disguising the other motives and intentions behind the merger. Interestingly, the owners and top managers also used moral arguments for abandoning the theranostics logic. For example, in his only public comment on the break-up, Pierre Fabre referred to a shutdown threat facing some of their units (in the company newsletter, reproduced in the local media).

It is noteworthy that this was the first reappearance of the newsletter, which had been discontinued after the merger with BioMérieux. At BioMérieux, in turn, the merger was no longer officially discussed. For example, the company website now reproduces a detailed history of the company without any reference to the merger. This "whitewashing" can be seen as an ultimate symbol of the delegitimation of the merger in collective consciousness.

\section{Discussion: Uncovering Pathological \\ Dynamics}

The BioMérieux-Pierre Fabre merger serves as a revealing case that highlights inherent risks and problems associated with discursive legitimation. Figure 2 summarizes the key discursive dynamics. This analysis leads to six important conclusions. First, discursive legitimation may have unintended consequences. The case serves as an example of how the merger justifications-this time the discourse on theranostics — can strongly influence the course of events in a pathological way. Although not everything in the case can be explained by discourse, this case is an illustrative example of the performative power of discourse; it shows how the discourse itself created unrealistic expectations and even illusionary ideas. In this sense, this analysis adds to our understanding of the problematic dynamics of merger processes (Jemison and Sitkin 1986, Haspeslagh and Jemison 1991) and the risks that are associated with overenthusiastic talk about specific synergies (Jemison and Sitkin 1986, Haunschild et al. 1994). 


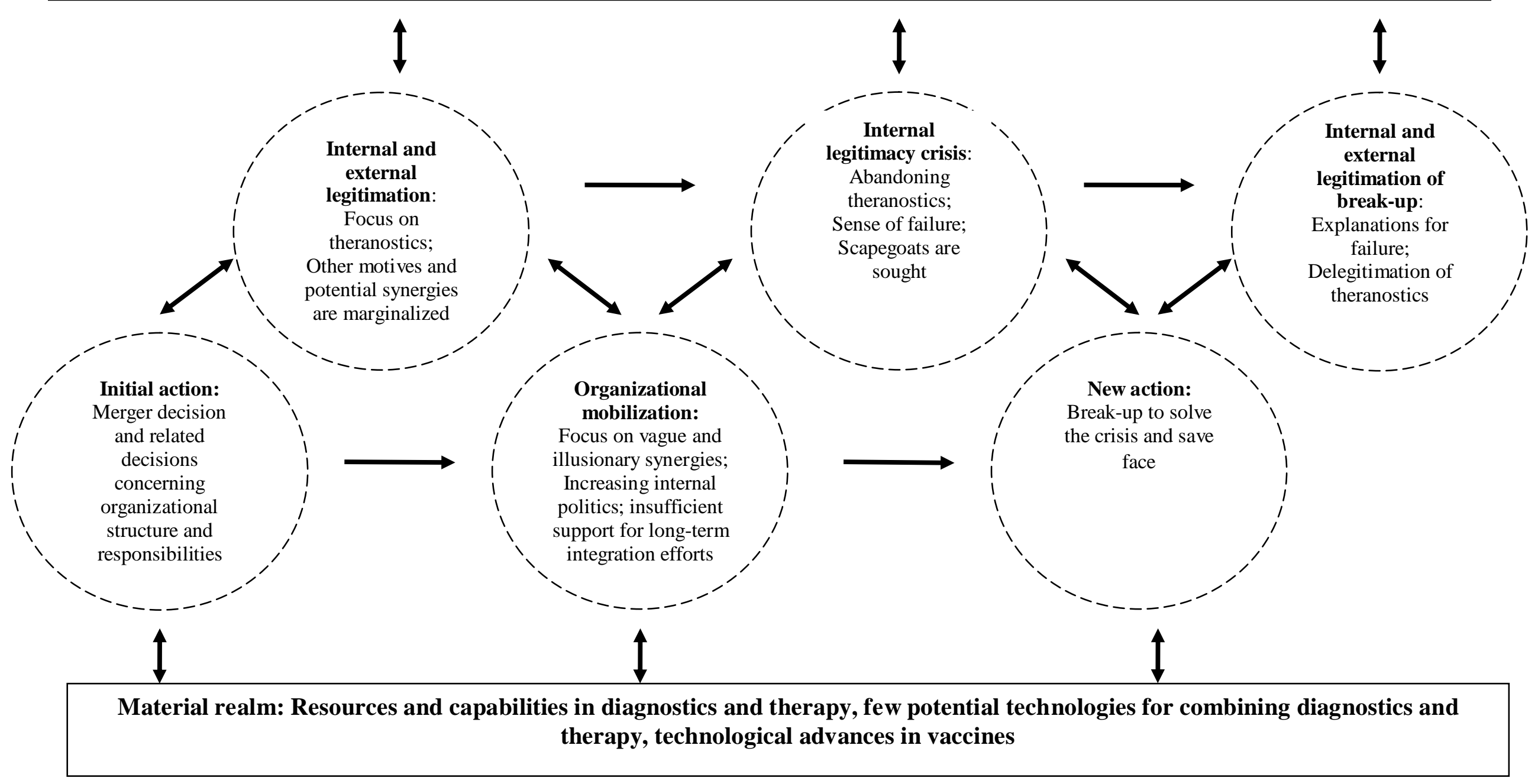

Figure 2: BioMérieux - Pierre Fabre as a pathological merger case 
Second, both sensegiving (Gioa and Chittipeddi 1991) and sensehiding are powerful mechanisms through which discourse impacts organizational action. In this case, the sensegiving effects are obvious, it was the increasing focus on theranostics that directed attention to this synergy in a way that retrospectively appears unrealistic and even illusionary and that distracted attention from an alternative and equally promising but more realistic scenario, in the vaccine business. The theoretical point is that this discourse became the primary sensemaking frame through which the legitimacy of the merger was built-and later questioned. Interestingly, this discourse gradually gained more and more momentum to the extent that it almost became a collective fallacy. The other mechanism - sensehiding — is, however, equally important. As the case shows, alternative synergies residing in the organization were not given much attention at all. This started with the gradual marginalization of other ideas in first communications and integration planning; it became most evident in the actual integration work. In particular, the combination of BioMérieux's Transgène and Pierre Fabre's CIPF was neglected, in terms of both concrete actions and communication. Retrospectively, one can speculate that giving more attention to this or other alternative synergies could have served as a means of avoiding the ultimate legitimacy crisis.

Third, this case analysis also highlights the inherently political nature of discursive legitimation and the risks associated with increasing politicization. As this case vividly illustrates, the merger process begins with a concrete need to legitimate a deal among various constituencies. This is important not only to ensure adequate support by stakeholders but also to enable mobilization of the organization for the integration work. In this case the top managers of the new organization planned a "story that could sell" (see also Demers et al. 2003) and later worked with communication specialists to ensure that the message would be as effective as possible. This case also shows how individuals can become champions of specific integration ideas and personify them within and outside the organizations. Such champions are evidently needed in postmerger integration (Haspeslagh and Jemison 1991), but this kind of championing may also increase the risks of focusing only on specific issues. This case is special in that we can also see how the integration efforts may lead to a legitimacy crisis. In this crisis, the legitimacy of the merger and the authority position of the owners and top management were intimately linked. Eventually, the merger was seen as a failure, and scapegoats were sought. This political pressure is also the key to understanding the following actions, most importantly the break-up decision. In particular, we can see how the absence of synergies was used as an argument to try to "save face" and "whitewash" this merger.

Fourth, this case also illustrates the risks involved with fashionable discourses and the central role of the media. The rhetorical power of specific discursive acts depends on how they resonate 
with broader regimes of truth or fashions (Abrahamson 1996, Creed et al. 2002). In this case, the enthusiasm surrounding "theranostics" was due to a large extent to a wider belief in "convergence" within the pharmaceutical industry. Interestingly, this case demonstrates how communication experts and journalists can play a major role precisely in reinforcing fashionable discourses such as theranostics. Communication experts can act as "spin doctors," helping to create enthusiasm but also creating unrealistic expectations in the longer run. The BMPF case provides additional support to the view that journalists play a central role in the legitimation and delegitimation of merger decisions in the public arena (Vaara et al. 2006). However, as this case illustrates, their reporting can also greatly influence what is said and done within merging organizations. This is not to say that journalists would always play a decisive role, but to emphasize that in today's society the media's reporting forms a central facet in organizational sensemaking (Kjaer and Slaatta 2007). In any case, this is an important aspect of contemporary mergers that has been overlooked in more traditional analyses of communication (Bastien 1987, Schweiger and DeNisi 1991).

Fifth, this analysis shows that there are a variety of general strategies-(de)naturalization, rationalization, authorization, and moralization-that can be used for legitimation and delegitimation. Although these categories are not exactly the same as those found in previous studies (Demers et al. 2003, Suddaby and Greenwood 2005, Vaara et al. 2006), our findings support the overall argument that legitimation strategies revolve around rationality, authority, and morality. However, the BMPF case highlights the central role of naturalization as a key discursive strategy. Indeed, our micro-level discursive analysis clearly shows that new merger cases are easily framed as "inevitable" or even a "necessity." This necessity is then supported by other, it is striking to see the radical reversals in the internal discussions as well as in the media coverage. Importantly, our case illustrates that the actual content of these discursive delegitimation strategies is different from the legitimation strategies. In particular, denaturalization is not simply the opposite of naturalization but a discursive strategy that questions the very basis of the merger in strong rhetorical terms. It is interesting to note that the delegitimation of rationalization and moralization includes more emotional elements, use of irony, and an overall critical tone. The delegitimation of authority in turn seems to readily imply discrediting and scapegoating. Moreover, the delegitimating discussion did not draw from other cases (exemplification) that seem to be so central in legitimation. Consequently, our findings support the view of Martin et al. (1990) that legitimation and delegitimation are not symmetrical processes, but involve strategies the use of which is dependent on the previous discussion. 
Sixth, in line with the critical realist view, this case shows the discursive legitimation also depends on concrete integration results. This is not to underestimate the power of discursive impression management, but to point out that "talking up" synergies is not enough in postmerger organizational change. As this merger vividly illustrates, such talking up can have dangerous consequences if expectations cannot be met. One interpretation-perhaps the easy one-is that the theranostic synergies were in the end unrealistic and illusionary in this case. Indeed, most of the people later admitted that that there were few concrete technologies or products that could have created theranostic synergies. From a critical realist perspective, another possible interpretation is that integration work was never given enough time or resources. In fact, one can argue that although the enthusiasm around theranostics reached unrealistic heights, the dramatic discrediting of all the long-term synergy potential was probably equally erroneous.

Although the BMPF is a special case, analogous discursive dynamics can be found in other mergers. The Daimler-Chrysler merger is a well-known example of how synergies were used to justify the merger, but where such synergies have been difficult to find (Shelton et al. 2004). It is interesting to note that while this article was being written, DaimlerChrysler was also facing a breakup, and the discussion around this case is very similar to that of BMPF. The AOL-Time Warner merger is a famous case where synergies related to the "new economy" were used to legitimate the merger, only to later prove limited or nonexistent (Bodie 2006). In recent cases such as MittalArcelor, it seems as if synergies were used as official justifications even though there was widespread speculation that the actual motives might be more related to power. The pharmaceutical industry has itself gone through a series of mergers and acquisitions (Schweizer 2005). It appears that in cases such as Astra-Zeneca (Hellgren et al. 2002) or Sanofi-Aventis (Mittra 2006), specific synergies have played a central role in official legitimation, whereas other concerns have been silenced. Without going any further, it seems that examples of "talked up" synergies and consequent integration problems are only too easy to find.

Yet one should be cautious when interpreting the findings of this case. The French setting is characterized by a "discussion culture," implying a special need to legitimate such business transactions. Also, the French media may have a particularly powerful effect on sensemaking because of the importance of social networks that cut across organizational boundaries. Further, the pharmaceutical industry has specific characteristics that should be taken seriously. For example, the synergies are often long-term ones, which may increase the risks of illusionary thinking. The extent to which the dynamics could be different in other national and industrial settings forms a major challenge for future research. 
The predominant view is that legitimation is a specific phase in merger or acquisition processes (Haspeslagh and Jemison 1991) or a phenomenon that is only loosely coupled with postmerger organizational action (Demers et al. 2003, Tienari et al. 2003). By outlining a recursive model of discursive legitimation and organizational action, we have intended to contribute to a fuller understanding of the dynamics of merger processes. In our model, discourse can have positive mobilizing effects, but it can also severely constrain organizational action. The point is that we are dealing with a dialectic that can produce new and unanticipated problems and challenges in the course of organizational integration.

By highlighting the problematic consequences of legitimation, this analysis provides a new explanation for the problems and failures frequently encountered in mergers and acquisitions (Haspeslagh and Jemison 1991, Paruchuri et al. 2006, Shaver 2006). In particular, this analysis increases our understanding of how unrealistic and even illusionary ideas about merger benefits are promoted to the detriment of integration. In this sense, this discursive analysis complements current understanding of the use of "fashionable" justifications to conceal empire building or hubris (Trautwein 1990, Thornton 1995, Seth et al. 2002), the role that rhetoric plays in reinforcing problematic cognitive and behavioral tendencies in decision making (Duhaime and Schwenk 1985, Jemison and Sitkin 1986, Haunschild et al. 1994), and the social and political challenges that organizational members face when dealing with integration decisions (Haspeslagh and Jemison 1991, Paruchuri et al. 2006). By linking media coverage to corporate communications and concrete decision making, this analysis also shows how the media can reinforce problems or even create crises (Tienari et al. 2003, Comtois et al. 2004, Vaara et al. 2006).

This study also contributes to the incumbent research on discursive legitimation (Creed et al. 2002, Demers et al. 2003, Suddaby and Greenwood 2005, Vaara et al. 2006). In particular, our model, which focuses on the recursiveness of action and discourse, adds to the previous studies focusing on the legitimation of specific actions (Hardy et al. 2000). Our perspective highlights the performative power of discourse but also emphasizes its linkages to broader discourses and concrete material practices. Thus, this view opens up a way to not only analyze discourse per se (Demers et al. 2003, Suddaby and Greenwood 2005, Vaara et al. 2006), but to take a stand as to which extent specific discourses may include unrealistic ideas, hypocrisy, or even illusions. Also, this analysis demonstrates how specific discursive strategies are used to turn previous arguments to their opposite 
and demonstrates how actors try to "save face" by such discursive strategizing. Thus, our analysis adds to the scarce studies examining reversals in legitimation or delegitimation (Martin et al. 1990).

This paper has followed a critical approach, and its broader implications should be taken seriously. As this case shows, preoccupation with dramatic business maneuvers and messages that "sell" may create false senses of "creation of value." Moreover, the spins around mergers and acquisitions may actually shift attention from far more important issues in ways that harm broader societal interests. One interpretation of the BMPF case is that the preoccupation with theranostics prevented the companies from focusing on and investing in immunological R\&D as much as they could have done otherwise. This is not to blame any single actor, but to emphasize that there is a need for critical analysis to uncover collective fallacies and harmful societal implications of the merger frenzy.

We believe that these critical theoretical ideas concerning discursive legitimation can, with due caution, be extended to other settings. This is the case with other types of radical organizational change such as alliances, greenfield investments, downsizing, shutdowns, or offshoring. In all these settings, one is likely to find analogous dynamics and pathological tendencies similar to the BMPF case. However, other processes where legitimating rhetoric creates fallacious expectations, obscures power conflicts, or harms social or societal interests can be examined from this kind of critical perspective. For example, issues such as hypes created around new product launches, grandiose announcements of new strategies, or CEO appointments with inflated expectations involve discursive dynamics that deserve critical scrutiny. In these and other contexts, one can often point to illusionary rhetoric and ensuing problems in fulfilling the unrealistic expectations, but also to very concrete material implications. Think, for example, about the social and societal costs of industrial shutdowns (Vaara and Tienari 2008) or the inequalities created by CEO pay escalation (Khurana 2002).

Our analysis has focused on a single case, and it would be important to examine others in different cultural and industrial contexts. Looking at the rhetorical and discursive processes in other "failures" but also "successes" would contribute to a fuller understanding of legitimation and the broader implications in mergers and acquisitions and other settings. It would be interesting to focus on cultural characteristics in legitimation and essential differences in discursive legitimation patterns. Such studies could involve cross-case analyses or focus on larger sets of textual data. Future studies should dig deeper into the discursive strategies used in legitimation (Martin et al. 1990, Suddaby and Greenwood 2005, Vaara et al. 2006). It would be useful to examine in more detail how variations in legitimation affect merger dynamics. For example, the unidimensionality of 
legitimation strategies, the mediatization of the discussion, and the degree of resonance among key stakeholders would be expected to increase the impact on subsequent organizational action. There is also a need to focus on delegitimation strategies and how they differ from legitimation. Such research could be linked with issues such as "whitewashing." Though our analysis has legitimation, one can go further in future studies.

Our analysis has also managerial implications. We emphasize the importance of healthy criticism, if not skepticism, when developing merger or acquisition plans. Our findings indicate that planning for any merger or acquisition should focus on concrete material and operational bases for integration - not only on the story to be told. This usually requires the inclusion of middle managers and experts whose knowledge is pivotal in terms of assessing the opportunities and obstacles in integration. Communication experts may help create enthusiasm, but corporate communication campaigns may paradoxically turn out to be the seeds of failure. In any case, one thing is clear: it is naïve to think of justification as only one task in merger or acquisition processes. Legitimation is an ever-present part of unfolding merger processes, and its management may be the trickiest thing of all.

\section{Acknowledgments}

The authors want to express their gratitude to Professor Sim Sitkin, who has played a crucial positive role as the editor in charge. They also wish to thank the three anonymous reviewers for their valuable insights. The authors are grateful to Yasmine Boughzala and Ouafa Ben Fathallah for collaboration in data gathering, Saku Mantere, and David Miller, Sally Riad, and Catherine Welch for help in cumbersome issues and useful suggestions to improve the paper.

\section{Appendix. Evolution of Theranostics Discourse}

The theranostics discourse is a distinctive part of the broader discourse of convergence of therapy and diagnostics. The concept first appears on August 3, 1998, in a press release by CardioVascular Diagnostics, Inc. (NASDAQ: CVDI). Mr John Funkhouser, President and Chief Executive Officer, announced the phase II success for a new test, referred to as a "theranostic test" (http://www.pharmacetics.com/press/aug3.98.html). For a little more than a year, there was little interest in the concept, except in the regular press releases by CVDI. 
On November 29, 1999, a leading international consulting firm, Cambridge Pharma Consulting, released its quarterly senior management briefing predicting the creation of a new industrial sector to harness the emerging trend of therapy-specific diagnostics: theranostics. Cambridge reported that although the future potential of genomics research was well known, many companies were overlooking the existing opportunities for theranostics.

The widespread diffusion of the concept started in 2000, when Clinica Reports issued its yearly publication, entitled "Theranostics: The influence of diagnostics on pharmaceutical Therapy." In a 115-page report, Clinica Reports laid the ground for a more widespread interest in and use of this term.

The popularity of the concept increased rapidly in 2000 among consulting firms. However, the concept had not yet appeared in France. In September 2000, when BioMérieux and Pierre Fabre announced their intent to merge, the concept had still not been mentioned in French publications. The companies themselves were not using this word for the combination of therapy and diagnostics either.

In early December 2000, Florence Bauchard, journalist and investigator for the monthly business journal Enjeux-Les Echos, published an important article called "Pharmacy: The Promise of "Theranostics." "For the first time, the term ("théranostic") appeared in a French publication. In an interview, she explained that she found most of her references and examples in Clinica Reports, although she expressed more reserve than the report did.

To complete this archaeological investigation, we searched various science databases to see whether the increasing interest among practitioners was echoed in the academic sphere. We could not find any published articles before 2000, and only one in 2000 (Medical Device Technology) and two in 2001 (Clinica Chimica Acta and Computer Assisted Radiology and Surgery).

These findings show how this discourse was first labeled by an entrepreneur, then theorized by a consulting company, and finally spread in the business community by gatekeepers such as journalists. Many people have perceived it as useful, but it still lacks scientific legitimacy. For example, it is rarely used in leading scientific publications.

\section{References}

Abrahamson, E. 1996. Management fashion. Acad. Management Rev. 21 254-281. 
Alvesson, M., D. Kärreman. 2000. Varieties of discourse: On the study of organizations through discourse analyses. Human Relations 53 1125-1151.

Arndt, M., B. Bigelow. 2000. Presenting structural innovation in an institutional environment: Hospitals' use of impression management. Admin. Sci. Quart. 45 494-524.

Ashforth, B. E., B. W. Gibbs. 1990. The double-edged sword of organizational legitimation. Organ. Sci. 1 177-195.

Bastien, D. T. 1987. Common patterns of behaviour and communication in corporate mergers and acquisitions. Human Resource Management 26 17-33.

Berger, P., T. Luckmann. 1966. The Social Construction of Reality. Doubleday, Garden City, NY.

Bodie, M. T. 2006. AOL Time Warner and the false god of shareholder primacy. J. Corporation Law $31975-1002$.

Bourdieu, P. 1998. On Television. The New Press, New York.

Brown, A. D., M. R. Jones. 2000. Honorable members and dishonourable deeds: Sensemaking, impression management and legitimation in the "Arms of Iraq Affair." Human Relations 53 655690.

Buono, A. F., J. L. Bowditch. 1989. The Human Side of Mergers and Acquisitions. Managing Collisions Between People, Cultures, and Organizations. Jossey-Bass, San Francisco.

Cartwright, S., C. L. Cooper. 1993. The psychological impact of merger and acquisition on the individual: A study of building society managers. Human Relations 46 327-347.

Clinica Reports. 2000. Theranostics: The influence of diagnostics on pharmaceutical therapy. PJB Ltd. 
Coff, R. W. 2002. Human capital, shared expertise and the likelihood of impasse in corporate acquisitions. J. Management 28 115-137.

Comtois, E., J.-L. Denis, A. Langley. 2004. Rhetorics of efficiency, fashion and politics: Hospital mergers in Quebec. Management Learn. 35 303-320.

Creed, D., M. Scully, J. Austin. 2002. Clothes make the person? The tailoring of legitimating accounts and the social construction of identity. Organ. Sci. 13 475-496.

Davis, G. 1994. A social movement perspective on corporate control. Admin. Sci. Quart. 31 141173.

Deephouse, D. L. 1996. Does isomorphism legitimate? Acad. Management J. 39 1024-1039.

Demers, C., N. Giroux, S. Chreim. 2003. Merger and acquisition announcements as corporate wedding narratives. J. Organ. Change Management 16 223-242.

Doyle, G. 2006. Financial news journalism: A post-Enron analysis of approaches toward economics and financial news production in the UK. Journalism_ Theory, Practice Criticism 4 433-452.

Dubois, A., L.-E. Gadde. 2002. Systematic combining: An abductive approach to case research. $J$. Bus. Res. 55 553-560.

Duhaime, I. M., C. R. Schwenk. 1985. Conjectures on cognitive simplification in acquisition and divestment decision making. Acad. Management Rev. 10 287-295.

Elsbach, K. D. 1994. Managing organizational legitimacy in the California cattle industry: The construction and effectiveness of verbal accounts. Admin. Sci. Quart. 39 57-88.

Elsbach, K. D., R. I. Sutton. 1992. Acquiring organizational legitimacy through illegitimate actions: A marriage of institutional and impression management theories. Acad. Management J. 35 699-738. 
Fairclough, N. 2003. Analysing Discourse_ Textual Analysis for Social Research. Longman, London.

Fairclough, N. 2005. Discourse analysis in organization studies: The case for critical realism. Organ. Stud. 26 915-939.

Fairclough, N., P. Thomas. 2004. The discourse of globalization and the globalization of discourse. D. Grant, C. Hardy, C. Oswick, L. Putnam, eds. The SAGEHandbook of Organizational Discourse. Sage, London, 379-396.

Fiss, P., E. Zajac. 2006. The symbolic management of corporate strategy: Framing, decoupling and strategic change. Acad. Management J. 49 1173-1193.

Foucault, M. 1994. Power_Essential Works of Foucault, 1954-1984, Vol. III. J. D. Faubion, ed. The New Press, New York.

Gertsen, M. C., A.-M. Søderberg, J. E. Torp, eds. 1998. Cultural Dimensions of International Acquisitions. Walter de Gruyter, Berlin.

Giddens, A. 1984. The Constitution of Society. University of California Press, Berkeley.

Gioia, D. A., K. Chittipeddi. 1991. Sensemaking and sensegiving in strategic change initiation. Strategic Management J. 12 433-448.

Grant, D., C. Hardy, C. Oswick, L. Putnam, eds. 2004. Organizational Discourse. Sage, London.

Green, S. E. 2004. A rhetorical theory of diffusion. Acad. Management Rev. 29 653-669.

Greenwood, R., C. R Hinings, J. Brown. 1994. Merging professional service firms. Organ. Sci. 5 $239-57$. 
Habermas, J. 1975. Legitimation Crisis. Beacon Press, Boston. Hambrick, D. C., A. A. Cannella. 1993. Relative standing: A framework for understanding departures of acquired executives. Acad. Management J. 36 733-762.

Hardy, C., N. Phillips. 1998. Strategies of engagement: Lessons from the critical examination of collaboration and conflict in an interorganizational domain. Organ. Sci. 9 217-230.

Hardy, C., N. Phillips. 2004. Discourse and power. D. Grant, C. Hardy, C. Oswick, L. Putnam, eds. The SAGEHandbook of Organizational Discourse. Sage, London, 299-316.

Hardy, C., I. Palmer, N. Phillips. 2000. Discourse as a strategic resource. Human Relations 53 12271248.

Hardy, C., D. Grant, T. Keenoy, C. Oswick, N. Phillips, eds. 2004. Special issue on Organizational Discourse. Organ. Stud. 25(1).

Haspeslagh, P. C., D. B. Jemison. 1991. Managing Acquisitions_Creating Value Through Corporate Renewal. The Free Press, New York.

Haunschild, P. R., A. Davis-Blake, M. Fichman. 1994. Managerial overcommitment in corporate acquisition processes. Organ. Sci. 5 528-540.

Hellgren, B., J. Löwstedt, L. Puttonen, J. Tienari, E. Vaara, A. Werr. 2002. How issues become constructed in the media: "Winners" and "losers" in the AstraZeneca merger. British J. Management $13123-140$.

Hirsch, P. M. 1986. From ambushes to golden parachutes: Corporate takeovers as an instance of cultural framing and institutional integration. Amer. J. Sociol. 91 800-837.

IBM Business Consulting Services. 2002. Pharma 2010 - The threshold of innovation, the future of the pharmaceutical industry. Janis, I. 1972. Victims of Groupthink. Houghton Mifflin, Boston. 
Jemison, D., S. Sitkin. 1986. Corporate acquisitions: A process perspective. Acad. Management Rev. 11 145-163.

Khurana, R. 2002. Searching for a Corporate Savior_ The Irrational Quest for Charismatic CEOs. Princeton University Press,

Princeton, NJ. Kitchener, M. 2003. Mobilizing the logic of managerialism in professional fields: The case of academic health care mergers. Organ. Stud. 23 391-420.

Kjaer, P., T. Slaatta. 2007. Mediating Business_The Expansion of Business Journalism. Copenhagen Business School Press, Copenhagen.

Kostova, T., S. Zaheer. 1999. Organizational legitimacy under conditions of complexity: The case of the multinational enterprise. Acad. Management Rev. 24 64-81.

Langley, A. 1999. Strategies for theorizing from process data. Acad. Management Rev. 24 691-710.

Larsson, R., S. Finkelstein. 1999. Integrating strategic, organizational, and human resource perspectives on mergers and acquisitions: A case survey of synergy realization. Organ. Sci. 10 1-27.

Leonardi, P. M., M. H. Jackson. 2004. Technological determinism and discursive closure in organizational mergers. J. Organ. Change Management 16 615-631.

Lubatkin, M. H., P. J. Lane. 1996. Psst _ _ _ the merger mavens still have it wrong! Acad. Management Executive 10 21-39.

Lubatkin, M. H., R. Calori, P. Very, J. F. Veiga. 1998. Managing mergers across borders: A twonation exploration of a nationally bound administrative heritage. Organ. Sci. 9 670-684.

Luckmann, T. 1987. Remarks on legitimation. Current Sociol. 35 109-115.

Martin, J., M. Scully, B. Levitt. 1990. Injustice and the legitimation of revolution: Damning the past, excusing the present, and neglecting the future. J. Personality Soc. Psych. 2 281-290. 
Miles, M., M. Huberman. 1994. Qualitative Data. Sage, Thousand Oaks, CA.

Mittra, J. 2006. The socio-political economy of pharmaceutical mergers: A case study of Sanofi and Aventis. Tech. Anal. Strategic Management 18 473-496.

Numagami, T. 1998. The infeasibility of invariant laws in management studies: A reflective dialogue in defense of case studies. Organ. Sci. 9 2-15.

Olie, R. 1994. Shades of culture and institutions in international mergers. Organ. Stud. 15 381-405.

Parsons, W. D. 1989. The Power of the Financial Press: Journalism and Economic Opinion in Britain and America. Edward Elgar, Aldershot, Cheltenham, UK.

Paruchuri, S., A. Nerkar, D. C. Hambrick. 2006. Acquisition integration and productivity losses in the technical core: Disruption of inventors in acquired companies. Organ. Sci. 17 545-562.

Patton, M. Q. 2002. Qualitative Research and Evaluation Methods. Sage, Thousand Oaks, CA.

Pettigrew, A. 1990. Longitudinal field research on change: Theory and practice. Organ. Sci. $1267-$ 292.

Phillips, N., C. Hardy. 2002. Discourse Analysis_Investigating Processes of Social Construction. Sage, Thousand Oaks, CA.

Phillips, N., T. B. Lawrence, C. Hardy. 2004. Discourse and institutions. Acad. Management Rev. 29 $635-652$.

Puranam, P., H. Singh, M. Zollo. 2006. Managing the coordinationautonomy dilemma in technology acquisitions. Acad. Management J. 49 263-280.

Reed, M. 2004. Getting real about organizational discourse. D. Grant, C. Hardy, C. Oswick, L. Putnam, eds. The SAGEHandbook of Organizational Discourse. Sage, London, 413-420. 
Rojo, L. M., T. van Dijk. 1997. “There was a problem, and it was solved!”: Legitimating the expulsion of "illegal” migrants in Spanish parliamentary discourse. Discourse Soc. 8 523-566.

Rouleau, L. 2005. Micro-practices of strategic sensemaking and sensegiving: How middle managers interpret and sell change every day. J. Management Stud. 42 1413-1441.

Schneider, S. C., R. L. M. Dunbar. 1992. A psychoanalytic reading of hostile takeover events. Acad. Management Rev. 17 537-567.

Schweiger, D. M., A. S. DeNisi. 1991. Communication with employees following a merger: A longitudinal field experiment. Acad. Management J. 34 110-135.

Schweizer, L. 2005. Organizational integration of acquired biotechnology companies in pharmaceutical companies: The need for a hybrid approach. Acad. Management J. 48 1051-1074.

Scott, W. R. 1995. Institutions and Organizations. Sage, Thousand Oaks, CA.

Seth, A., K. P. Song, R. Pettit. 2002. Value creation and destruction in cross-border acquisitions: An empirical analysis of foreign acquisitions of U.S. firms. Strategic Management J. 23 921-940.

Shaver, J. M. 2006. A paradox of synergy: Contagion and capacity effects in mergers and acquisitions. Acad. Management Rev. 31 962-976.

Shelton, C. D., R. F. Hall, J. R. Darling. 2004. When cultures collide: The challenge of global integration. Eur. Bus. Rev. 15 312-323.

Stahl, G. K., M. E. Mendenhall. 2005. Managing Culture and Human Resources. Stanford University Press, Stanford, CA.

Staw, B. M., P. I. McKechnie, S. M. Puffer. 1983. The justification of organizational performance. Admin. Sci. Quart. 28 582-600. 
Suchman, M. C. 1995. Managing legitimacy: Strategic and institutional approaches. Acad. Management Rev. 20 571-611.

Suddaby, R., R. Greenwood. 2005. Rhetorical strategies of legitimacy. Admin. Sci. Quart. 50 35-67.

Thornton, P. H. 1995. Accounting for acquisition waves: Evidence from the U.S. college publishing industry. W. R. Scott, S. Christensen, eds. The Institutional Construction of Organizations. Sage, Thousand Oaks, CA, 199-225.

Tienari, J., E. Vaara, I. Björkman. 2003. Global capitalism meets national spirit: Discourses in media texts on a cross-border acquisition. J. Management Inquiry 12 377-393.

Tsoukas, H. 1989. The validity of idiographic research explanations. Acad. Management Rev. 14 $551-561$.

Trautwein, F. 1990. Merger motives and merger prescriptions. Strategic Management J. 11 283-295.

Vaara, E. 2003. Post-acquisition integration as sensemaking: Glimpses of ambiguity, confusion, hypocrisy, and politicization. J. Management Stud. 40 859-894.

Vaara, E., J. Tienari. 2008. A discursive perspective on legitimation strategies in MNCs. Acad. Management Rev. 33 985-993.

Vaara, E., J. Tienari, J. Laurila. 2006. Pulp and paper fiction: On the discursive legitimation of global industrial restructuring. Organ. Stud. 27 789-810.

Van Dijk, T. 1997. Discourse Studies_A Multidisciplinary Introduction, Vols. 1 and 2. Sage, London.

Van Dijk, T. A. 1998. Ideology_A Multidisciplinary Analysis. Sage, London.

Van Leeuwen, T., R. Wodak. 1999. Legitimizing immigration control: A discourse historical analysis. Discourse Stud. $183-118$. 
Weber, M. 1947. The Theory of Social and Economic Organization. The Free Press, New York.

Wodak, R. 2004. Critical discourse analysis. C. Seale, G. Gobo, J. F. Gubrium, D. Silverman, eds. Qualitative Research Practice. Sage, London, 197-213.

Yin, R. 2005. Case Study Research. Design and Methods. Sage, Thousand Oaks, CA. 